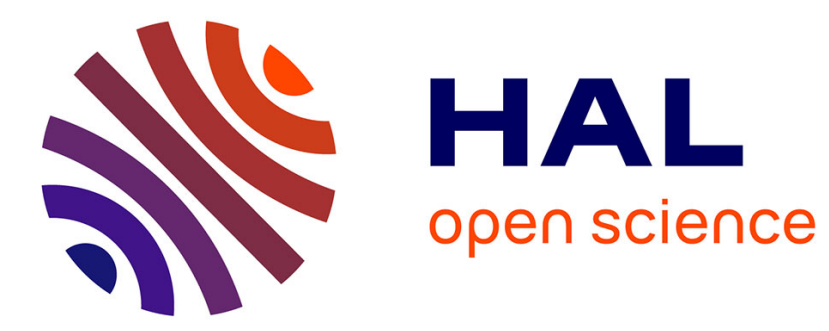

\title{
Vegetation composition and structure of some Neotropical mountain grasslands in Brazil
}

\author{
Soizig Le Stradic, Elise Buisson, G. Wilson Fernandes
}

\section{To cite this version:}

Soizig Le Stradic, Elise Buisson, G. Wilson Fernandes. Vegetation composition and structure of some Neotropical mountain grasslands in Brazil. Journal of Mountain Science, 2015, 12 (4), pp.864-877. 10.1007/s11629-013-2866-3 . hal-01445158

\section{HAL Id: hal-01445158 https://hal.science/hal-01445158}

Submitted on 9 May 2018

HAL is a multi-disciplinary open access archive for the deposit and dissemination of scientific research documents, whether they are published or not. The documents may come from teaching and research institutions in France or abroad, or from public or private research centers.
L'archive ouverte pluridisciplinaire HAL, est destinée au dépôt et à la diffusion de documents scientifiques de niveau recherche, publiés ou non, émanant des établissements d'enseignement et de recherche français ou étrangers, des laboratoires publics ou privés. 


\title{
Vegetation Composition and Structure of Some Neotropical Mountain Grasslands in Brazil
}

\author{
LE STRADIC Soizig 1,*, ORCID: oooo-0003-2643-3544 ; E-mail : soizig.lestradic@gmail.com \\ BUISSON Elise ${ }^{2}$, ORCID: oooo-0002-3640-8134 ; E-mail: Elise.Buisson@univ-avignon.fr \\ FERNANDES G. Wilson 3, ORCID: oooo-0oo3-1559-6049 ; E-mail: gw.fernandes@gmail.com \\ 1 Gembloux Agro-Bio Tech, Université de Liège, Biodiversité et paysage, Passage des Déportés, 2, 503o, \\ Gembloux, Belgium
}

2 Institut Méditerranéen de Biodiversité et d'Ecologie marine et continentale (IMBE), Université d'Avignon et des Pays de Vaucluse, UMR CNRS IRD Aix Marseille Université, IUT site Agroparc, BP 61207, F-84911 Avignon cedex 09, France

3 Ecologia Evolutiva \& Biodiversidade / Instituto de Ciências Biológicas, Universidade Federal de Minas Gerais, 30161-97o Belo Horizonte MG, CP 486, Brazil

\begin{abstract}
The description and understanding of plant communities is fundamental for the implementation of conservation or restoration programs, especially when these communities are highly threatened and need to be restored. Campos rupestres, some Neotropical mountain grasslands located in central Brazil and part of the Cerrado biome (covering 2 million $\mathrm{km}^{2}$ ) host unique plant communities, currently threatened by quarrying and mining. The grassy matrix of campos rupestres, has long been considered a rich mosaic under the control of local topography and the nature of substrate, but this affirmation has not been well studied. We analyzed whether plant communities varied in relation to edaphic factors within the stony substrate and the sandy substrate of this grassy matrix. We selected 5 sites where occur both grasslands on stony substrate and on sandy substrate, and we carried out vegetation surveys and soil analyses. We counted 222 plant species within our communities, among which $38.6 \%$ are exclusively found on campos rupestres. Our results show that both soil-types are strongly acidic, nutrient poor and exhibit a seasonal variation. Phosphorus increases and $\mathrm{pH}$ and organic carbon decrease during the dry season. Stony soils are slightly richer in nutrients than sandy soils and differences in soil granulometry and composition have led to the formation of distinct plant communities. Some species are confined to either one or the other grassland-type, which makes the plant composition of each community unique. Variations in edaphic factors generate heterogeneous grasslands favorable to a high plant diversity. Conservation programs and restoration actions have to maintain or recreate this heterogeneity. The presence of distinct plant communities implies that different strategies might be adopted to improve the restoration of these ecosystems.
\end{abstract}

Keywords: Biodiversity; campos rupestres; herbaceous communities; Rupestrian grasslands; Serra do Cipó.

\section{Introduction}

In 2004, the Parties of the Convention on Biological Diversity (CBD) adopted a work program on mountain biological diversity in order to improve knowledge on the functioning and composition of mountain ecosystems (CBD 2004), a fundamental tool to implement any conservation network. Indeed, the CBD recognized the fragility of mountain ecosystems and species and their vulnerability to anthropogenic and natural disturbances, particularly in the current context of land-use and climate changes. Mountain 
ecosystem conservation is essential for many reasons: they host a great biodiversity, they act as refuges for species, they are important for water resources since mountains play a critical role in the water cycle (FAO 1998, Price 1998). Excluding the Andean vegetation, there are three main highland vegetation formations in South America, the Tepuis on the Guayana shield, campos de altitude (i.e. Brazilian páramos) and campos rupestres, both in Brazil.

Campos rupestres (which means rupestrian grasslands) are species-rich tropical ecosystems occurring at altitudes ranging from $800 \mathrm{~m}$ to $2000 \mathrm{~m}$ along the Espinhaço range mountain in south-eastern Brazil and often included in the Cerrado domain (Brazilian savanna, the richest tropical savannah in the world, covering 22\% of the country). Campos rupestres is described primarily as a more or less continuous herbaceous stratum with scattered rocky outcrops that harbour small sclerophyllous evergreen shrubs and sub-shrubs (Giulietti et al. 1997). However Giulietti et al. (1997) noted that rather than a homogeneous vegetation type, these campos rupestres are an assemblage of communities forming a rich mosaic under the control of local topography and the nature of substrate, with rocky outcrops, grasslands and some bogs situated along streams. Campos rupestres are constrained ecosystems, their soils are shallow, acidic and coarsely textured, with high aluminum and low nutrient content (Benites et al. 2003, 2007). Despite these harsh conditions, these grasslands are important centers of biodiversity (Giulietti et al. 1987, 2005; Lara and Fernandes 1996; FAO 1998; Carvalho et al. 2012) and represent one of the highest levels of endemism in the Cerrado biome (Alves and Kolbek 1994; Giulietti et al. 1997; Silva and Bates 2002; Echternacht et al. 2011).

Human disturbances of campos rupestres began in the $18^{\text {th }}$ century, and were mainly associated with mining activities (i.e. gold, precious stones, iron, manganese) in the region. Nowadays degradations are also associated to an increase in uncontrolled anthropogenic burnings and in fire frequency (while natural fires are a rare event, farmers burn grasslands annually to stimulate grass regrowth in order to support cattle breeding), wood extraction, eucalyptus plantation, harvesting of ornamental plants (orchids, bromeliads, Eriocaulaceae) (Giulietti et al. 1997), and road construction (Barbosa et al. 2010). While threats increase, limited data on conservation targets, such as plant communities (Heywood and Iriondo 2003), hamper the conservation and the restoration of these campos rupestres. Indeed, to implement a conservation network, lists of habitats (described by their environmental characteristics and their plant communities) and species that are recognized as being of interest are necessary. A conservation network such as NATURA 2000 in Europe, for example, is a network of areas designed to protect the most seriously threatened habitats and species across Europe (European Commission 2000). Thereby, the recognition, precise description, and understanding of plant communities are fundamental tools to implement conservation networks and restoration projects (Soulé and Kohm 1989; Alves and Kolbek 2010).

So far, most of the studies carried out on campos rupestres dealt with the shrubby physiognomy occurring on rocky outcrops (Meguro et al. 1994; Conceição and Pirani 2005; Conceição et al. 2007; Jacobi et al. 2007; Scarano 2007), but very few studies addressed the variation of plant communities in the herbaceous layer (Conceição and Pirani 2005; Viana and Lombardi 2007; Borges et al. 2011), whereas it represent the matrix and thus the quintessence of these grasslands. In this grass layer, a mosaic of different pedoenvironments, which sustain abrupt changes, have already been highlighted (Benites et al. 2003; Alves and Kolbek 2010; Carvalho et al. 2012; Figure 1a), and should lead to the variation of plant communities. However this assumption has not been experimentally tested within the grassy matrix of campos rupestres, while these community variations may explain the extremely rich biodiversity of these tropical grasslands.

Within this framework we analyzed the soils, the composition and structure of two grassland-type communities, one located on stony substrate and the other one located on sandy substrate, but both located within the grass matrix of campos rupestres and we assessed whether plant communities varied in relation to edaphic factors.

\section{Material and Methods}

\subsection{Study area and sites}

Our study took place in Brazil, in the southern portion of the Espinhaço Range, one of the largest mountain range in Brazil recognized as Biosphere Reserve by UNESCO in 2005 and representing over $30000 \mathrm{~km}^{2}$ (UNESCO 2005). Study areas were located in the Environmental Protected Area Morro da Pedreira, in the buffer zone of the Serra do Cipó National Park (state of Minas Gerais). Campos rupestres are the main 
vegetation formation in the Serra do Cipó region, totalling more than 1600 plant species (Giulietti et al. 1987). The regional climate is classified as Cwb with a warm temperature, a dry winter and a warm summer, according to the Köppen's system (Köppen 1900). It is markedly seasonal, with two distinguishable seasons, a rainy season from November to April and a dry one from May to October. The mean annual precipitation and temperature are respectively $1622 \mathrm{~mm}$ and $21.2^{\circ} \mathrm{C}$ (Madeira and Fernandes 1999).

We selected 5 sites, where occur both herbaceous communities, growing on either a sandy substrate that we called sandy grasslands hereafter (Figure $1 \mathrm{~b}$ ) or on a stony substrate that we called stony grasslands hereafter (Figure 1c). Within a site, the selected sandy grassland and stony grassland were close together, separated from each other by a minimum of $10 \mathrm{~m}$ and a maximum of $500 \mathrm{~m}$. Sites are between 1 ha and 5 ha. These substrates are the two main in campos rupestres. All sites were located between $1100 \mathrm{~m}$ and $1300 \mathrm{~m}$.

\subsection{Plant survey}

We surveyed fifteen $1 \mathrm{~m}^{2}$ quadrats at each sandy grassland site $(\mathrm{n}=5)$ and twenty $1 \mathrm{~m}^{2}$ quadrats at each stony grassland site $(\mathrm{n}=5)$ according to the minimal area which was previously assessed in December 2008 for each grassland type (species/area curves - Mueller-Dombois and Ellenberg 1974). Contrary to soil samples taken both at the dry and wet season, the vegetation was surveyed only once. Because a large majority of the species are perennial, community composition is not expected to change much during the year. At each quadrat the following information was collected: (1) percent cover of bare ground, litter, moss and lichen (hereafter "cryptogams"), forbs, ligneous species, Velloziaceae (a shrubby-looking characteristic family of campos rupestres), and graminoids; (2) a list of the species, (3) the abundance of each species (number of individuals or clumps per $\mathrm{m}^{2}$ ), (4) the percent cover of each species visually estimated, based on the vertical projection of all aerial plant parts (Mueller-Dombois and Ellenberg 1974), (5) the frequency of each species, based on the number of subquadrats $\left(2520 \mathrm{~cm} \times 20 \mathrm{~cm}\right.$ subquadrats $\left./ \mathrm{m}^{2}\right)$ in which each species was found. Plants were identified by experts and by using specific literature (Giulietti et al. 1987; Forzza et al. 2010) and the Herbarium BHCB at the Universidade Federal de Minas Gerais in Belo Horizonte, Brazil. Voucher specimens were conserved at the LEEB laboratory at the Universidade Federal de Minas Gerais in Belo Horizonte.

In order to find out whether the two grassland types had different plant communities, the Importance Value Index (IVI - Mueller-Dombois and Ellenberg 1974) and Relative Dominance were calculated for each species and at each site. The IVI is the sum of the Relative Density $\left(D_{r}\right)$, the Relative Dominance $\left(D o_{r}\right)$ and the Relative Frequency $\left(F_{r}\right)$ and allows a species with high frequency but low cover to be considered as important. IVI was used to compare the importance of each species (maximum value $=300$ ): the higher is the IVI, the higher is the importance of the species (Muller-Dombois and Ellenberg 1974). As $D_{r}, D o_{r}$ and $F_{r}$ are proportions, they range from o to 100.

1) The Relative Density $\left(D_{r}\right)$ is $D_{r}=100 \times D_{a} / D_{t}$, where $D_{a}$ (Absolute Density) is the number of individuals / $\mathrm{m}^{2}$ and $D_{t}$ (Total Density) is the sum of the all the $D_{a}$. The Absolute Density is $D_{a}=\Sigma n_{i} \times S / A$ with $n_{i}=$ number of individuals of species $i, S=$ quadrat area, $A=$ total area of sampling at the site.

2) The Relative Dominance $\left(D o_{r}\right)$ is $D o_{r}=100 \times D o_{a} / D o_{t}$, where $D o_{a}$ (Absolute Dominance) is the area in $\mathrm{cm}^{2}$ occupied by the species $/ \mathrm{m}^{2}$ and $D o_{t}$ (Total Dominance) is the sum of the all the $D o_{a}$. The Absolute Dominance $\left(\mathrm{cm}^{2} / \mathrm{m}^{2}\right)$ is $D o_{a}=100 \times \Sigma R_{i} \times S_{i} / A$ with $R_{i}=$ area covered by species i (percent cover), $S_{i}=$ plot area, $A=$ total area of sampling at the site.

3) The Relative Frequency $\left(F_{r}\right)$ is $F_{r}=100 \times F_{a} / F_{t}$, where $F_{a}$ (Absolute Frequency) is the percent of subquadrats occupied by the species at a site and $F_{t}$ (Total Frequency) the sum of the all the $F_{a}$. The Absolute Frequency is $F_{a}=100{ }^{*} \Sigma S q_{i} / S q_{t}$ with $S q_{i}=$ number of subquadrats occupied by species $i$ and $S q_{t}=$ total number of subquadrats / site.

In order to analyze the characteristics (i.e. geographic distribution, endemism and IUCN threatening status) of the species, all species were classified according to (1) life-form according to Raunkiaer's life form modified by Mueller-Dombois and Ellenberg (1974), (2) their plant forms, (3) habitats, (4) distribution ranges, (5) IUCN status and (6) life cycle. (1) The life-forms were assessed according to Raunkiaer (1904) modified by Mueller-Dombois and Ellenberg (1974). While the life-form system was elaborated to characterize plant strategies during the cold season, it can still be of some use in tropical systems with regular disturbances because position of buds is not solely a consequence of climatic conditions, but also a 
consequence of regular disturbances. (2) The considered plant forms were: forbs, graminoids, sub-shrub, shrub, liana, fern. (3) Habitats in Brasil were determined based on literature: campos rupestres, altitude grassland, cerrado (sensu-lato including rupestrian grasslands), caatinga, Atlantic rainforest, Amazon rainforest, wet grassland (Giulietti et al. 1987; Lista de Espécies da Flora do Brasil 2013). (4) The distribution ranges, also based on the literature and a database, comprised: (a) endemic from the Serra do Cipó, (b) endemic from the Espinhaço Range in the state of Minas Gerais, (c) endemic from the Espinhaço Range (states of Minas Gerais and Bahia), (d) distributed in the state of Minas Gerais, (e) distributed in Brazil, (f) wide distribution (Giulietti et al. 1987; Lista de Espécies da Flora do Brasil 2013; database SpeciesLink). (5) The IUCN status was defined according to Mendonça and Lins (2000): vulnerable, critical, and endangered. (6) We also included the life cycle: perennial or annual.

\subsection{Soil analyses}

Soil analyses were carried out on 60 soil samples, 6 taken at each of the 10 grassland sites. At each grassland site, 3 soil samples were taken during the rainy season (February) and 3 during the dry season (July). For each sample, three subsamples of soil were randomly gathered in the 10 first centimetres in the vicinity of a randomly selected vegetation quadrat before being pooled. To assess the granulometry of the coarse fraction of the soil, each sample was sieved through $1 \mathrm{~cm}$ and $2 \mathrm{~mm}$ mesh sieves. The fine fraction $\left(<2 \mathrm{~mm}\right.$ ) was used for physical (granulometry) and chemical (pH, MO, total N, P, K, $\mathrm{Mg}^{2+}, \mathrm{Ca}^{2+}, \mathrm{Al}^{3+}$ ) soil analyses: $\mathrm{P}$ and $\mathrm{K}$ in $\mathrm{mg} / \mathrm{dm}^{3}, \mathrm{~N}$ and $\mathrm{C}$ in $\mathrm{dag} / \mathrm{kg}, \mathrm{Mg}^{2+}, \mathrm{Al}^{3+}, \mathrm{Ca}^{2+}$ in cmolc/ $\mathrm{dm}^{3}$, Organic Carbon $\left(\mathrm{C}_{\text {org }}\right)$ in dag/kg. P, N and K were analysed with the Mehlich 1 extraction method; $\mathrm{Ca}^{2+}, \mathrm{Mg}^{2+}$, $\mathrm{Al}^{3+}$ with $1 \mathrm{~mol} / \mathrm{L} \mathrm{KCl}$ extraction; COrg following the Walkley-Black method. Analyses were conducted at the soil laboratory of Viçosa Federal University, Viçosa, Minas Gerais, Brazil. Soil analysis followed the recommendations of EMBRAPA (1997).

\subsection{Statistical analyses}

To compare vegetation composition and structure of the two grasslands, different tests were carried out. To assess plant similarity between stony and sandy grasslands, the Steinhaus similarity index, based on species abundance, was calculated (Steinhaus $=1$-Bray-Curtis index, values range between 1 and 0 , the higher the Steinhaus value, the more similar plant compositions, Legendre and Legendre 1998). To assess the differences of the Steinhaus index when comparing sites belonging to the same or to different types of grasslands, we performed a Generalized Linear Model (GLM) procedure using a Gaussian distribution and identity link function, with similarity index as the response variable, the modality (comparison between stony and sandy grasslands, within stony grasslands and within sandy grasslands) as explicative variables, by setting the site effect as an offset component of the GLM. An offset specifies an a priori known component to be included in the linear predictor during fitting.

To identify groups, a ward clustering of a matrix of chord distances among sites was performed using species percent cover data. Then, to corroborate classifications and find out if the cluster overlapped or not, we plotted the cluster membership using a correspondence analysis (CA) on plant percent cover matrix (222 species $\times 175$ quadrats). We therefore identified which species discriminated each groups to establish the community type. To test the difference between the two grassland types in the number of species per site and per $\mathrm{m}^{2}$, paired $t$-tests were performed.

To compare soil composition and structure of the two grasslands, different tests were performed. To compare the fine fraction granulometry between campo rupestre types, paired t-tests were performed after checking the data for normality and homogeneity of variance. To compare the coarse fraction granulometry between grassland types, the paired t-test with estimated separate variance was performed as the variances were not homogeneous. To compare chemical soil composition between grassland types and seasons we used a nested two-way ANOVA for each chemical element. Log-transformations were applied before comparing P, K, $\mathrm{Ca}^{2+}, \mathrm{Mg}^{2+}$ and Organic Carbon (Sokal and Rohlf 1998).

To analyse the relationship between soil and plant composition, a co-inertia analysis was run between plant and soil data. This type of analysis is used to determine if there is a co-structure between two data tables by performing simultaneous analysis of the two tables. The optimizing criterion in co-inertia analysis is that the resulting sample scores (environmental scores and floristic scores) are the most covariant (Doledec and Chessel 1994). The co-inertia analysis was based on one correspondence analysis (222 species) and one 
Principal Component Analysis PCA (11 physico-chemical variables) at the 10 sites (10 points); a test based on permutations was performed to find out about the co-inertia significance. All analyses were carried out in $\mathrm{R}$ version 2.9.1 (R Core Development Team 2010) using ADE-4 and stats packages.

\section{Results}

\subsection{Plant community comparison}

The similarity between sites from different grassland types was significantly lower than the similarity within sites from the same grassland type (mean Steinhaus similarity index of $0.25 \pm 0.07$ between sites from different grasslands, $0.46 \pm 0.04$ within sites of sandy grassland and $0.40 \pm 0.06$ within sites of stony grassland, GLM procedure $P<0.001)$. Furthermore, differences in similarity were significant between and within both grasslands ( $\mathrm{R}$ between stony and sandy grasslands $=0.49, \mathrm{R}$ within stony grasslands $=0.45$ and $\mathrm{R}$ within sandy grasslands $=0.29, P<0.001$ ), highlighting also the presence of a higher heterogeneity within stony grassland communities compared to sandy grassland communities.

A Ward clustering analysis allowed the discrimination of two distinct floristic groups based on floristic composition and structure, the sandy grasslands on one side and the stony grasslands on the other side (Figure 2). Correspondence analysis allowed to visualize this distinction. Axes 1 and 2 of the CA performed on plant percent cover explained $47 \%$ of the total inertia. Axis 1 (29\%) separated sandy from stony grasslands while axis $2(18 \%)$ showed an inter-site variability in plant composition, particularly in the stony grasslands (Figure 3).

Some species, such as Vellozia albiflora, V. resinosa, V. caruncularis, Bulbostylis lombardii, B. paradoxa, Diplusodon orbicularis, Xyris minarum, X. melanopoda, Paepalanthus geniculatus, Sebastiana ditassoides and Vochysia pygmaea were typical of the stony grasslands, while Xyris asperula, X. insignis, $X$. nubigena, Syngonanthus cipoensis, Panicum cyanescens, Vellozia epidendroides and Rhynchospora ciliolata were strongly associated with sandy grasslands (Figure 3). The main Poaceae species, such as Tatianyx arnacites, Mesosetum exaratum and Homolepis longispicula, can be found in both grassland types, but with different importance indices and dominance values. According to the IVI and dominance values, the sandy grasslands were characterized by Tatianyx arnacites, Homolepis longispicula, Paspalum erianthum, Lagenocarpus tenuifolius and Mesosetum exaratum. These five dominant species represented $56.4 \%$ of the vegetation cover while the first 16 dominant species accounted for $80.0 \%$ of the vegetation cover (Supplementary online material, Appendix 1). In the stony grasslands, Mesosetum exaratum, Tatianyx arnacites, Lagenocarpus tenuifolius, Homolepis longisticula and Xyris minarum can be considered the main species based on their IVI values, while Vellozia resinosa and V. caruncularis can be characterized as important, having important dominance values (Appendix 1). The top five most dominant species represented $51.3 \%$ of the vegetation cover while the top 19 dominant species accounted for $80 \%$.

\subsection{Soil analyses}

As expected, grasslands with a stony substrate (stony grasslands) presented a significantly greater proportion of gravel (gravel $>1 \mathrm{~cm}$ represented $28 \%$ ) compared to grasslands with a sandy substrate (sandy grasslands) (Table 1) and sandy grasslands had a significantly higher proportion of fine sand $(<2 \mathrm{~mm})$ than stony grasslands ( $\mathrm{t}=4.65, \mathrm{P}<\mathrm{O} .001)$ (Table 1$)$. In stony grasslands, $\mathrm{N}, \mathrm{P}, \mathrm{K}, \mathrm{Ca}^{2+}, \mathrm{Mg}^{2+}$ concentrations and $\mathrm{C}_{\text {org }}$ content were significantly higher and the soil was more acidic than in sandy grasslands (Table 2, Figure 4). Both grasslands presented seasonal variation for $\mathrm{P}$ and $\mathrm{C}_{\text {org }}$ content and $\mathrm{pH}$. During the dry season, $\mathrm{P}$ concentrations were significantly higher while $\mathrm{C}_{\text {org }}$ contents and $\mathrm{pH}$ were significantly lower (Table 2, Figure 4). The aluminum concentration did not vary between grasslands or between seasons (Table 2, Figure 4).

\subsection{Relationships between vegetation and soil}

A strong co-structure between soil and vegetation data was observed $(\mathrm{RV}=0.70, P<0.001)$, revealing a significant relationship between the soil composition and the species composition of the different communities (Figure 5). Axis 1 (79.4\%) showed the distinction between the stony and sandy grasslands (Figure 5a). Stony grasslands are characterized by higher concentrations of nutrient such as $\mathrm{N}, \mathrm{K}, \mathrm{Ca}^{2+}$, 
$\mathrm{Mg}^{2+}$ concentrations and $\mathrm{C}_{\text {org }}$ content while the sandy grasslands are characterized by finer soil and a less acidic $\mathrm{pH}$ (Figure 5b). Axis 2 (10.5\%) showed the heterogeneity within each grassland-type, mainly characterized by variation in $\mathrm{Al}^{3+}$ (Figure $5 \mathrm{~b}$ ), heterogeneity which is higher within stony grasslands compared to sandy grasslands (Figure 5).

\subsection{Conservation value of campos rupestres}

In the 10 sandy and stony grasslands that were investigated, we found one species of pteridophytes and 221 species of angiosperms, 120 monocotyledons and 101 dicotyledons, distributed into 34 plant families (Appendix 1). We recorded 158 species in the sandy grasslands and 170 species in the stony grasslands of which $13.9 \%$ and $17.1 \%$ were endemic species, respectively (Table 3 ).

Around one third of the species are restricted to one or the other grasslands, $32.9 \%$ of species (52 species) are exclusively found in sandy grasslands while $37.6 \%$ of species (64 species) are restricted to stony grasslands, which confirms the significant heterogeneity of the grass layer of campos rupestres. The mean number of species $/ \mathrm{m}^{2}(t=2.93, P<0.01)$ as well as the mean number of shrubs $(\mathrm{W}=1, P<0.05)$ were higher in the stony grasslands (Table 3, Appendix 1).

These ecosystems can be defined as graminoid lands rather than common tropical grasslands (Figure 6) because, besides the importance of Poaceae species (26 and 28 species in sandy and stony grasslands, respectively), other graminoid families were very well represented such as Cyperaceae (23 and 25 species), Xyridaceae (20 and 14 species), Eriocaulaceae ( 9 and 14 species). Among the most characteristic families of such ecosystems we can also cited Velloziaceae ( 5 and 7 species) for the Monocotyledons and Asteraceae (14 and 13 species), Melastomataceae ( 6 and 8 species), Polygalaceae ( 7 and 1 species) and Apocynaceae ( 4 and 5 species) for the Dicotyledons (Figure 6). This original family composition confers to these graminoid lands a high interest value for conservation.

Graminoids (representing $45 \%$ and $51 \%$ of species in sandy and stony grasslands, respectively) were clearly the dominant plant form in both communities. Forbs (25\% and $26 \%$ of species in sandy and stony grasslands, respectively) and sub-shrubs (17\% and 21\%) were also well represented. Shrubs, lianas and ferns represent $7 \%$ of the species in sandy grasslands and $8 \%$ in stony grasslands. In both sandy and stony grasslands, a large majority of species are hemicryptophytes (i.e. $82 \%$ of species in sandy grasslands and $81 \%$ of species in stony grasslands). Chamaephytes represent $8 \%$ of species in sandy grasslands and $11 \%$ of species in stony grasslands while geophytes represent $3 \%$ and $4 \%$ of the species in sandy and stony grasslands respectively. Other life forms (hemicryptophytes lianas, nano-phanerophytes and therophytes) represent around $5 \%$ of the species in both grasslands. A large part of the species is perennial in both communities and monocotyledons represent $56.9 \%$ in sandy grasslands and $55.9 \%$ in stony grasslands (Table 3). Only $5.3 \%$ of all species (12 species) were found in all sites while $39 \%$ of species ( 87 species) were encountered at only one site (singletons).

The distribution pattern of 174 species showed that $12.6 \%$ of the total number of species (i.e. 28 species) are endemic to the Serra do Cipó, while $21.6 \%$ of species ( 48 species) are restricted to the Espinhaço range whether in the state of Minas Gerais or in the states of Bahia and Minas Gerais (Figure 7). Among the 160 species for which bibliographical data were available, $38.6 \%$ of species ( 86 species) are restricted to the campos rupestres and $13.9 \%$ of species (31 species) are cerrado species (Figure 7). 10.7\% of species (i.e. 24 species) are classified as either endangered, critical, or vulnerable according to the IUCN criteria (Table 3, Appendix 1).

\section{Discussion}

\subsection{Plant communities linked to soil composition and structure}

One of the main findings of this study was the stark heterogeneity of the grassy matrix of campos rupestres, with at least two distinct plant communities occurring: one on the sandy substrate and one on the stony substrate. Some species are restricted to one or another grassland, such as Paspalum hyalinum, Xyris asperula and X. insignis in sandy grasslands and Paepalanthus nigrescens, Prestelia eriopus, Marcetia acerosa and Vellozia albiflora in stony grasslands. This composition heterogeneity leads to an overall high 
plant diversity and an exceptional intrinsic value to each grassland type..

The co-inertia analysis showed that each plant community is closely related to a specific soil composition. The stony grasslands are characterized by a coarse granulometry, particularly quartzic stones, which is the result of greater water erosion. In the same way, stony grasslands are rarely flooded while sandy grasslands can experience temporary flooding during the rainy season (Vitta 1995), we then expect stony grasslands to be drier than sandy grasslands. This is illustrated by the important presence in stony grasslands of Vellozia spp., which are strongly associated with such dry environments (Porembski and Barthlott 2000). In dry systems, water availability is a source of heterogeneity (Jobbagy et al. 1996), and local drainage further diversifies the environment by creating relatively humid or arid sites. This might explain why higher heterogeneity is observed within the stony grasslands compared to the sandy grasslands. Nonetheless heterogeneity within each grassland-type is low compared to the heterogeneity between grassland-types.

The nature of the substrate and its heterogeneity, even at a scale of a few centimeters, separate the grassland types from one another. Our data indicate that the soil of stony grasslands is more acidic and richer in nutrients $\left(\mathrm{N}, \mathrm{P}, \mathrm{K}, \mathrm{Ca}^{2+}, \mathrm{Mg}^{2+}\right)$ and carbon content than sandy grassland soil, which explain in part the discrimination of the two plant communities. As sandy grasslands are less subject to water erosion during the rainy season, they accumulate water, which slowly percolates, and this might facilitate the eluviation of the soluble organic compounds that are associated with iron and aluminum and can leach through and into deeper soil. This translocation is favored by humic acid, which is common in these soils (Schaeffer and Ker 2003). Normally, at lower pH, phosphorus (a critical element in the development of the vegetation (Sarmiento 1984)) precipitates, for example, with aluminum, and becomes less available to plants. However, in the stony grasslands we studied, it was found that during the dry season, soil pH decreased while phosphorus concentrations increased in what may be related to a reduction in the loss of mineral nutrients due to the absence of rainfall (Sarmiento 1984). The extreme abiotic conditions of the campos rupestres have strong consequences in terms of plant adaptation to constrained environmental conditions. However, as each campo rupestre physiognomy is characterized by its own constraints (e.g. type of substrate), different adaptations can be observed between both grassland types (see Carvalho et al. 2012, Negreiros et al. 2014).

\subsection{Main characteristics of campos rupestres flora}

Both sandy and stony grasslands are species-rich plant communities highlighting the relevance of campos rupestres for the maintenance of an important biodiversity. On the contrary to other tropical grasslands or savannas dominated by grasses (Poaceae), both studied grassland-types of campo rupestre are dominated first by a graminoid strata with Poaceae (Paspalum, Andropogon) and Cyperaceae (Lagenocarpus, Rhynchospora, Bulbostylis), combined with Xyridaceae (Xyris), Eriocaulaceae (Paepalanthus, Leiothrix, Syngonanthus), Velloziaceae (Vellozia, Barbacenia) and Iridaceae (Trimezia, Pseudotrimezia). The predominance of monocotyledons, which has already been noted in earlier botanical surveys of campos rupestres (Meguro et al. 1994; Conceição and Pirani 2005; Viana and Lombardi 2007; Borges et al. 2011), indicates the presence of limiting ecological factors according to Granville (1984). Globally the soils of campos rupestres are poor in nutrients. Clays, which are usually associated with a higher capacity of nutrient retention, are almost entirely absent. This pattern might have been exacerbated by periods of intense leaching followed by long-term podzolization, an important process that occurs in these highaltitude ecosystems (Turenne 1970; Benites et al. 2007). The marked dominance of hemicryptophytes is characteristic of savannas and tropical grasslands and particularly in Cerrado and campos sulinos (Overbeck and Pfadenhauer 2007) and underline the high capacity of campos rupestres species to resprout after fire. However, we suggest that it could be interesting to adopt a new life-form classification in order to take into account the large variety of underground storage organs found in tropical ecosystems (Stanton 1988) and illustrate the diversity of life forms in such ecosystems.

\subsection{Conservation value of campos rupestres}

Heterogeneity within the grassy matrix of campos rupestres favored an important biodiversity with high level of endemism in both studied grassland-types. Seventy percent of Vellozia species are restricted to the Espinhaço Range (Mello-Silva 1995). In addition Giulietti et al. (1987) noted that a large number of Eriocaulaceae species are endemic to the Espinhaço Range. For Xyridaceae, Wanderley (2011) recorded 14 endemic taxa in the Serra do Cipó and attributed the recent origin of Xyris species to explain their restricted distribution. Despite the lack of geographically broader studies, many campo rupestre species 
have been said to be endangered because of their restricted distribution (Ribeiro and Freitas 2010). Numerous species (38.6\%) are found exclusively on campos rupestres, suggesting a uniqueness to this ecosystem, though vicarious species can contribute to a high floristic variation among them (Giulietti et al. 1997; Alves and Kolbek 2010). Alves and Kolbek (2010) have already noted that genera alone are not sufficient to separate campos rupestres from other vegetation formations, such as highland grasslands (campos de altitude), and that floristic studies at the species-level must be combined with environmental variables to help design general functioning patterns for the campos rupestres.

Both grasslands are threatened by increasing mining, quarrying and eucalyptus plantations, which is why designing conservation areas and elaborating restoration protocols are urgent matters. However variations in edaphic factors which generate heterogeneous grasslands have to be taking into account when conservation and restoration programs are implemented to maintain or recreate this heterogeneity favorable to the high plant diversity. More specific measures should be taken to conserve endemic species. The potential changes in Brazilian environmental legislation may weaken the already modest conservation requirements for the region, thereby increasing the threat to campo rupestre biodiversity and the ecosystem services they provide. The conservation of pristine areas and the restoration of already degraded ones are more than urgent and necessary.

\section{Conclusions}

Campos rupestres are species-rich Neotropical mountain grasslands, occurring on harsh abiotic conditions with nutrient poor soils. We demonstrated that plant communities varied in relation to edaphic factors within the grassy matrix. Some species are confined to one or the other grassland type, highlighting finely tuned adaptations to environmental conditions. This heterogeneous matrix is favorable to a rich biodiversity with high level of endemism. Our study also brings to light the lack of information on numerous species, underscoring the need for research on their biology, distribution and ecology. These findings have important implications for the conservation and restoration of these grasslands.

\section{Acknowledgements}

We are grateful to Shishir Paudel, Thierry Dutoit, Yumi Oki, Frederico de Siqueira Neves, José Eugênio Côrtes Figueira, and anonymous reviewers for their suggestions on the text, to Benoit Loeuille (Asteraceae), Pedro Lage Viana (Poaceae), Renato de Mello-Silva (Velloziaceae), Livia Echternacht (Eriocaulaceae), Nara de O. Mota Furtado (Xyridaceae), Fernando A. O. Silveira (Melastomataceae) for their assistance in the botanical identifications. We would like to thank Kolo D. Wamba from PROEDITING (San Diego, CA) for review the English of the manuscript. This work was carried out with grants from the Conselho Nacional de Pesquisa (CNPq 561883/2010-6), Fundação de Amparo à Pesquisa do Estado de Minas Gerais (FAPEMIG: APQ-04105-10), RTP CNRS-CEMAGREF “Ingénierie Ecologique” [Ecological Engineering] SAVER SAVanna Ecological Restoration, Natural Reserva Vellozia and the Ministère Français des affaires étrangères et européennes (EGIDE).

Electronic Supplementary Material: Supplementary material (Appendix 1) is available in the online version of this article at http://dx.doi.org./10.1007/s11629-013-2866-3.

\section{References}

Alves RJV, Kolbek J (2010) Can campo rupestre vegetation be floristically delimited based on vascular plant genera? Plant Ecology 207:67-79. DOI: 10.1007/s11258-009-9654-8.

Alves RJV, Kolbek J (1994) Plant species endemism in savanna vegetation on table mountains (Campo Rupestre) in Brazil. Vegetatio 113:125-139. DOI: 10.1007/BFoo044230.

Barbosa NPU, Fernandes GW, Carneiro MAA, et al. (2010) Distribution of non-native invasive species and 
soil properties in proximity to paved roads and unpaved roads in a quartzitic mountainous grassland of southeastern Brazil (campos rupestres). Biological Invasions 12: 3745-3755. DOI: 10.1007/s10530-010$9767-y$.

Benites VM, Caiafa AN, Mendonça ES, et al. (2003) Solos e vegetação nos complexos rupestres de altitude da Mantiqueira e do Espinhaço [Soils and vegetation of the altitudinal rupestrian complexes of Mantiqueira and Espinhaço]. Floresta e Ambiente 10: 76-85. (In portuguese)

Benites VM, Schaefer CEGR, Simas FNB, Santos HG (2007) Soils associated with rock outcrops in the Brazilian mountain ranges Mantiqueira and Espinhaço. Revista Brasileira de Botânica 30: 569-577. DOI: $10.1590 /$ So100-84042007000400003

Borges RAX, Carneiro MAA, Viana PL (2011) Altitudinal distribution and species richness of herbaceous plants in campo rupestres of the Southern Espinhaço range, Minas Gerais, Brazil. Rodriguesia 62:139152.

Carvalho F, Souza FA, Carrenho R, Moreira FMS, Jesus EC, Fernandes GW (2012) The mosaic of habitats in the high-altitude Brazilian rupestrian fields is a hotspot for arbuscular mycorrhizal fungi. Applied Soil Ecology 52: 9-19. DOI: 10.1016/j.apsoil.2011.10.001.

Conceição AA, Pirani JR, Meirelles ST (2007) Floristics, structure and soil of insular vegetation in four quartzite-sandstone outcrops of " Chapada Diamantina ", Northeast Brazil. Revista Brasileira de Botânica 30: 641-656. DOI: 10.1590/S0100-84042007000400009.

Conceição AA, Pirani JR (2005) Delimitação de habitats em campos rupestres na Chapada Diamantina, Bahia: substratos, composição floristica e aspectos estruturais [Habitat delimitation in campos rupestres of the Chapada Diamantina, Bahia: substrate, floristic composition and structure]. Boletim de Botânica da Universidade de São Paulo 23:85-111. (In portuguese)

Convention on Biological Diversity (2004) The programme of work on mountain biological diversity ; [cited 2013 Aug 24], in: http://www.cbd.int/mountain/about.shtml

Coutinho LM (1990) Fire in the ecology of the Brazilian Cerrado. In: Goldammer JG (ed.), Fire in the Tropical Biota: Ecosystem Processes and Global Challenges. Springer Verlag, Berlin, Germany. pp 82105.

Dolédec S, Chessel D (1994) Co-inertia analysis: an alternative method for studying species-environment relationships. Freshwater Biology 31: 277-294. DOI: 10.1111/j.1365-2427.1994.tbo1741.x.

Echternacht L, Trovó M, Oliveira CT, et al. (2011) Areas of endemism in the Espinhaço Range in Minas Gerais. Flora 206: 782-791. DOI: 10.1016/j.flora.2011.04.003.

EMBRAPA - EMPRESA BRASILEIRA DE PESQUISA AGROPECUÁRIA (1997) Manual de métodos de análise de solo [Soil analysis handbook]. 2nd ed. Embrapa Solos, Rio de Janeiro, Brazil. p 212. (In portuguese)

European Commission (2000) Natura 2000, Managing our heritage. Luxembourg, Luxembourg.

European Commission (2007) Interpretation manual of European Union habitats (http://ec.europa.eu/environment/nature/legislation/habitatsdirective/docs/2007_07_im.pdf , accessed on 2013-08-24)

FAO (1998) Unasylva - Moving mountains. Food and Agriculture Organization of the United Nations, Rome, Italy.

Giulietti AM, Menezes NA, Pirani JR, Wanderley MGL (1987) Flora da Serra do Cipó: caracterização e lista das espécies [Serra do Cipó flora: characteristics and species list]. Boletim de Botânica da Universidade de São Paulo 9:1-151. (In portuguese)

Giulietti AM, Pirani JR, Harley RM (1997) Espinhaço range region: eastern Brazil. In: Davis SD et al. (eds.), Centre of plants diversity: a guide and strategy for their conservation. World Wildlife Fund / World Conservation Union, Cambridge, UK. pp 397-404.

Giulietti AM, Harley RM, Queiroz LP, et al. (2005) Biodiversity and Conservation of Plants in Brazil. Conservation Biology 19: 632-639. DOI: 10.1111/j.1523-1739.2005.00704.x.

Granville JJ (1984) Monocotyledons and pteridophytes indicators of environmental constraints in the tropical vegetation. Candollea 39: 265-269.

Heywood VH, Iriondo JM (2003) Plant conservation: old problems, new perspectives. Biological Conservation 113: 321-335. DOI: 10.1016/So006-3207(03)00121-6.

Jacobi CM, Carmo FF, Vincent RC, Stehmann JR (2007) Plant communities on ironstone outcrops: a diverse and endangered Brazilian ecosystem. Biodiversity and Conservation 16: 1-17. DOI: 10.1007/s10531-007-9156-8.

Jobbágy EG, Paruelo JM, León RJC (1996) Vegetation heterogeneity and diversity in flat and mountain landscapes of Patagonia (Argentina). Journal of Vegetation Science 7:599-608. DOI: 10.2307/3236310.

Köppen W (1900) Versuch einer Klassifikation der Klimate, vorzugsweise nach ihren Beziehungen zur Pflanzenwelt [Climate classification attempt, mainly according to its relationship with plant world]. Geographische Zeitschrift 6: 593-611, 657-679.

Lista de Espécies da Flora do Brasil (2013) [Species list of Brazil flora] (http://floradobrasil.jbrj.gov.br/2 
accessed on 2014-01-19). (In portuguese)

Lara AC, Fernandes GW (1996) The highest diversity of galling insects: Serra do Cipó, Brazil. Biodiversity Letters 3: 111-114.

Legendre P, Legendre L (1998) Numerical Ecology, 2nd ed. Amsterdam (Netherlands): Elsevier science BV.

Madeira J, Fernandes GW (1999) Reproductive phenology of sympatric taxa of Chamaecrista (Leguminosae) in Serra do Cipó. Journal of Tropical Ecology 15: 463-479.

Meguro M, Pirani JR, Giulietti AM, Mello-Silva R (1994) Phytophysiognomy \& composition of the vegetation of Serra do Ambrósio, Minas Gerais, Brazil. Revista Brasileira de Botânica 17: 149-166.

Mello-Silva R (1995) Aspectos taxonômicos, biogeográficos, morfológicos e biológicos das Velloziaceae de Grão-Mogol, Minas Gerais, Brasil. [Taxonomic, biogeographic, morphologic and biological aspects of Velloziaceae of Grão-Mogol, Minas Gerais, Brazil] Boletim de Botânica da Universidade de São Paulo 14: 49-79. (In portuguese)

Mendonça MP, Lins LV (2000) Lista Vermelha das Espécies Ameaçadas de Extinção da Flora de Minas Gerais [Red list of threatened plant species of Minas Gerais]. Biodiversitas \& Fundação Zoo-Botânica de Belo Horizonte, Belo Horizonte, Brazil. (In portuguese)

Mueller-Dombois D, Ellenberg H (1974) Aims and methoods in vegetation ecology. John Wiley \& Sons, New York, US. p 547.

Negreiros D, Le Stradic S, Fernandes GW, Rennó HC (2014) CSR analysis of plant functional types in highly diverse tropical grasslands of harsh environments. Plant Ecology 215: 379-388. DOI: 10.1007/s11258014-0302-6

Overbeck GE, Pfadenhauer J (2007) Adaptive strategies in burned subtropical grassland in southern Brazil. Flora 202: 27-49. DOI: 10.1016/j.flora.2005.11.004.

Pirani JR, Mello-Silva R, Giulietti AM (2003) Flora de Grão-Mogol, Minas Gerais, Brasil [Grão-Mogol flora, Minas Gerais, Brazil]. Boletim de Botânica da Universidade de São Paulo 21: 1-24. (In portuguese)

Porembski S, Barthlott W (2000) Granitic and gneissic outcrops (inselbergs) as centers of diversity for desiccation-tolerant vascular plants. Plant Ecology 151: 19-28. DOI: 10.1023/A:1026565817218

Price MF (1998) Mountains: globally important ecosystems. UNASYLVA-FAO 195: 3-12.

R Development Core Team (2010) R: A language and environment for statistical computing. Vienna (Austria): R Foundation for Statistical Computing.

Ribeiro KT, Freitas L (2010) Impactos potenciais das alterações no Código Florestal sobre a vegetação de campos rupestres e campos de altitude [Potential impacts of environmental code alteration on campo rupestre and campo de altitude vegetation]. Biota Neotropica 10: 1-8. (In portuguese)

Sarmiento G (1984) The ecology of Neotropical Savannas. Harvard University Press, Cambridge, UK. p 235.

Scarano FR (2007) Rock outcrop vegetation in Brazil: a brief overview. Revista Brasileira de Botânica 30: 561-568. DOI: 10.1590/So100-84042007000400002

Schaefer CE, Ker JC (2003) Solos e vegetação nos complexos rupestres de altitude da mantiqueira e do espinhaço [Soils and vegetation of the altitudinal rupestrian complexes of Mantiqueira and Espinhaço]. Floresta e Ambiente 10: 76-85. (In portuguese)

Silva JMC, Bates JM (2002) Biogeographic Patterns and Conservation in the South American Cerrado : A Tropical Savanna Hotspot. Bioscience 52:225-234. DOI: 10.1641/ooo63568(2002)052[0225:BPACIT]2.0.CO;2

Sokal RR, Rohlf FJ (1998) Biometry: The Principles and Practice of Statistics in Biological Research. $3^{\text {rd. }}$ WH Freeman and Co, New York, US. p 776.

Soulé ME, Kohm KA (1989) Research Priorities for Conservation Biology. Island press, Washington, US. p 97.

SpeciesLink (2002), (http://splink.cria.org.br/, accessed on 2014-01-19).

Stanton NL (1988) The underground in grasslands. The annual review of ecology and systematics 19: 573589. DOI: 10.1146/annurev.es.19.110188.003041

Turenne JF (1970) Influence de la saison des pluies sur la dynamique des acides humiques dans les profils ferrallitiques et podzoliques sous savanes de Guyane française [Wet season influence on humic acid dynamics in the ferrallitic and podzolic layers of savannas in French Guyana]. Cahier ORSTOM 8:419449. (In French)

UNESCO (2005) Biosphere reserve in Latin America and the Caribbean,

(http://www.unesco.org/new/en/natural-sciences/environment/ecological-sciences/biospherereserves/latin-america-and-the-caribbean/, accessed on 2014-01-19).

Viana LP, Lombardi JA (2007) Floristica e caracterização dos campos rupestres sobre canga na Serra da Calçada, Minas Gerais, Brasil [Floristic and characterization of canga campos rupestres in the Serra da Calçada, Minas Gerais, Brazil ]. Rodriguesia 58:159-177. (In portuguese)

Vitta FA (1995) Composição florística e ecologia de comunidades campestres na Serra do Cipó, Minas Gerais [Floristic composition and ecology of grassland communities in the Serra do Cipó]. Master's thesis, Universidade de São Paulo, São Paulo, Brazil. (In portuguese) 
Wanderley MG (2011) Flora da Serra do Cipó, Minas Gerais: Xyridaceae [Serra do Cipó flora, Minas Gerais: Xyridaceae]. Boletim de Botânica da Universidade de São Paulo 29:69-134. (In portuguese). DOI: 10.11606/issn.2316-9052.v29i1p69-134.

White PS, Jentsch A (2001) The search for generality in studies of disturbance and ecosystem dynamics. Progress in Botany 62: 399-450.

Zappi DC, Lucas E, Stannard B, et al. (2003) Lista das plantas vasculares de Catolés, Chapada Diamantina, Bahia, Brasil [Vascular plant list of Catolés, Chapada Diamantina, Bahia, Brazil]. Boletim de Botânica da Universidade de São Paulo 21: 345-398. (In portuguese)

Table 1 Mean and standard error values of granulometric soil parameters, from soils collected in 5 sandy and 5 stony grasslands (3 samples / site , $n=30$ ).

$\begin{array}{ll}\begin{array}{l}\text { Coarse fraction } \\ \text { of soil }\end{array} & \text { soil }>1 \mathrm{~cm}(\%) \\ & \text { soil }>2 \mathrm{~mm}(\%)\end{array}$

Fine fraction of Coarse sand $(\mathrm{dag} / \mathrm{kg})$ soil $<2 \mathrm{~mm}$ Fine sand (dag/kg) Silt (dag/kg) Clay (dag/kg)

\section{Sandy grasslands}

$1.79 \pm 0.71$

$12.98 \pm 2.42$

$19.66 \pm 2.48$

$46.87 \pm 2.04$

$29.27 \pm 1.94$

$4.20 \pm 0.43$

\section{Stony grasslands $\boldsymbol{t}$ value}

$27.63 \pm 1.18$

$18.81^{* * *}$

$60.04 \pm 1.89$

$16.26^{* * *}$

$25.80 \pm 2.42 \quad 1.63^{\mathrm{ns}}$

$37.33 \pm 1.41 \quad 4.65^{* * *}$

$31.53 \pm 1.49 \quad 0.85^{\text {ns }}$

$5.33 \pm 0.47 \quad 1.54^{\text {ns }}$

Notes: T-tests were run using separate variance estimates for the coarse fraction. ns: non-significant difference, ${ }^{* * *}$ : significant difference with $P<0.001$.

Table 2 Results of the two-way ANOVAs performed for chemical soil parameters, from soils collected in 5 sandy and 5 stony grasslands ( 3 samples / site / season, $n=60$ ) (Units for $\mathrm{Ca}^{2+}, \mathrm{Mg}^{2+}, \mathrm{Al}^{3+}$ : cmolc/dm 3 ; Unit for N, Organic carbon : $\mathrm{dag} / \mathrm{kg}$; Units for $\left.\mathrm{P}, \mathrm{k}: \mathrm{mg} / \mathrm{dm}^{3}\right)$.

Two-way ANOVAs: $F$

$\begin{array}{llll} & \text { Season } & \text { G-type } & \text { Interaction } \\ \mathrm{N} & 1.09^{\mathrm{ns}} & 8.69^{*} & 1.93^{\mathrm{ns}} \\ \mathrm{pH}\left(\mathrm{H}_{2} \mathrm{O}\right) & 41.99^{* * *} & 9.26^{*} & 0.17^{\mathrm{ns}} \\ \mathrm{P} & 188.26^{* * *} & 6.34^{*} & 3.49^{\mathrm{ns}} \\ \mathrm{K} & 2.63^{\text {ns }} & 15.04^{* *} & 1.68^{\mathrm{ns}} \\ \mathrm{Ca}^{2+} & 3.09^{\mathrm{ns}} & 18.53^{* *} & 0.63^{\mathrm{ns}} \\ \mathrm{Mg}^{2+} & 0.23^{\text {ns }} & 19.37^{* *} & 0.79^{\mathrm{ns}} \\ \mathrm{Al}^{3+} & 0.94^{\text {ns }} & 0.14^{\text {ns }} & 0.82^{\text {ns }} \\ \text { Organic carbon } & 6.83^{*} & 23.18^{* *} & 4.73^{*}\end{array}$

Notes: G-type: Grassland type; ns: non-significant difference, ${ }^{*}$ : significant difference with $P<0.05,{ }^{* * *}$ : significant difference with $P<0.001$.

Table 3 Family and species distribution between sandy ( 5 sites, 15 quadrats / site, $n=75$ ) and stony grasslands ( 5 sites, 20 quadrats / site, $\mathrm{n}=100$ ). 


\begin{tabular}{|c|c|c|c|}
\hline & Sandy-gl & Stony-gl & $t$-test \\
\hline Total no. of families & 33 & 34 & \\
\hline Total no. of species & 158 & 170 & \\
\hline Total no. of dicotyledons & $68(43.1 \%)$ & $74(43.5 \%)$ & \\
\hline Total no. of monocotyledons & $90(56.9 \%)$ & $95(55.9 \%)$ & \\
\hline Total no. of pteridophyte & - & $1(0.6 \%)$ & \\
\hline Total no. of annual plants & $7(4.4 \%)$ & $3(1.8 \%)$ & \\
\hline Total no. of perennial plants & $151(95.6 \%)$ & $167(98.2 \%)$ & \\
\hline Total no. of species endemic from the Serra Do Cipó & $22(13.9 \%)$ & $29(17.1 \%)$ & \\
\hline Total no. of species with an endangered/vulnerable/critical statue & $15(9.5 \%)$ & $22(12.9 \%)$ & \\
\hline No. of species / site & $81.0 \pm 2.7$ & $85.8 \pm 2.5$ & $t=1.28 \mathrm{~ns}$ \\
\hline No. of species / m² & $26.8 \pm 0.6$ & $29.1 \pm 0.5$ & $t=2.93^{*}$ \\
\hline
\end{tabular}

Notes: Sandy-gl: Sandy grassland; Stony-gl: Stony grasslands; ns: non significant difference, *: significant difference with $P<0.05$.

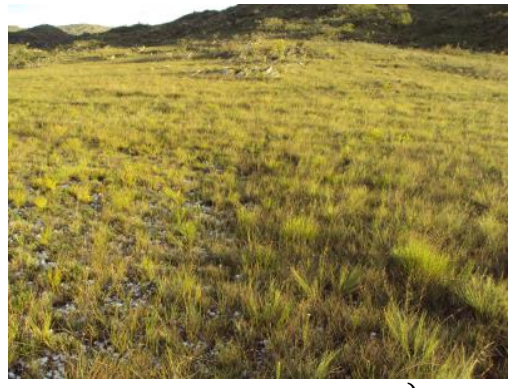

a)

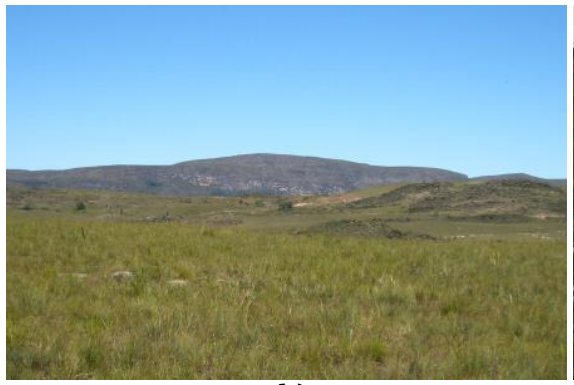

b)

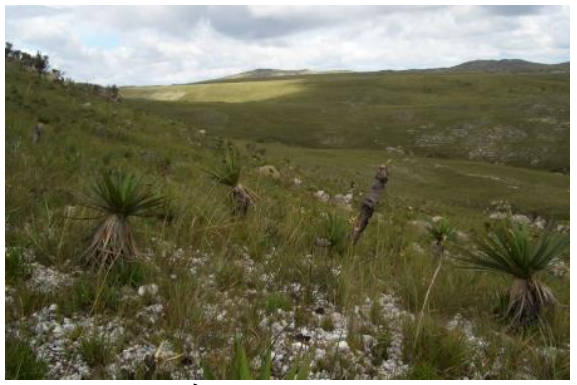

c)

Figure 1 a) The herbaceous layer of campos rupestres are generally confounded and defined as a more or less continuous herbaceous layer. However some herbaceous communities seems to exist, separated by few centimeters, the stony grasslands on the left side of the picture and the sandy grassland on the right side; b) Picture of a sandy grassland; c) Picture of a stony grassland. Photo credit: Soizig Le Stradic.

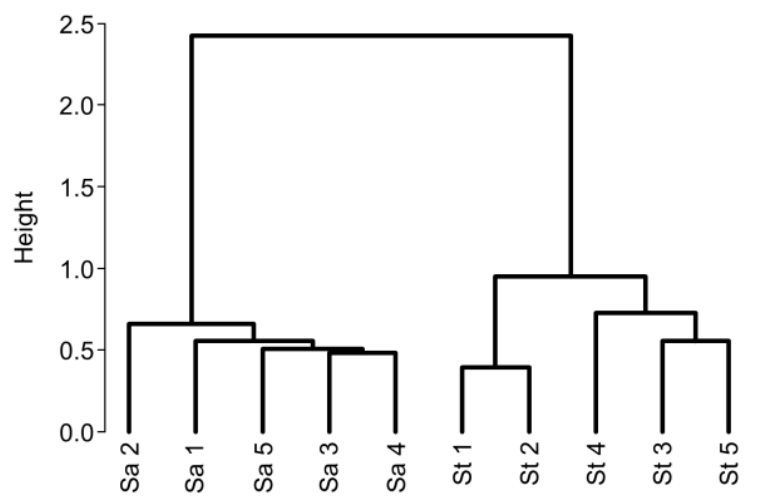

Figure 2 Ward clustering of a matrix of chord distances among sites (species data). Sa- = sandy campo rupestre grasslands and St- = stony sandy campo rupestre grasslands. 


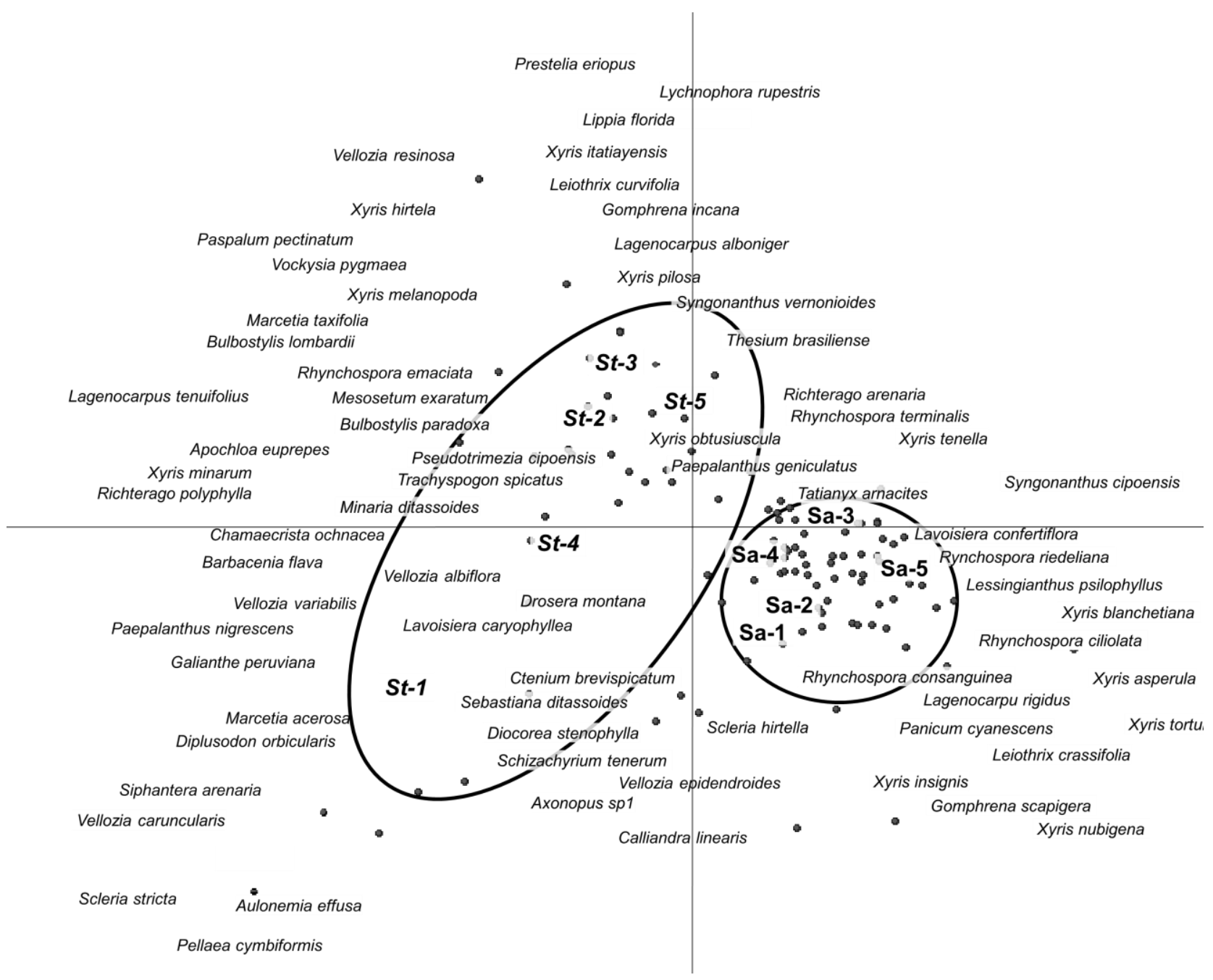

Figure 3 Correspondence analysis run on the matrix of plant percent cover in $1 \mathrm{~m}^{2}$ quadrats in the 5 sandy (Sa) and 5 stony (St) grasslands [175 points $\times 222$ species]. Projection of the two first axes, axis $1(29 \%)$ and axis $2(18 \%)$. Inertia= $0.19, P<0.001$, Monte-Carlo permutations. 

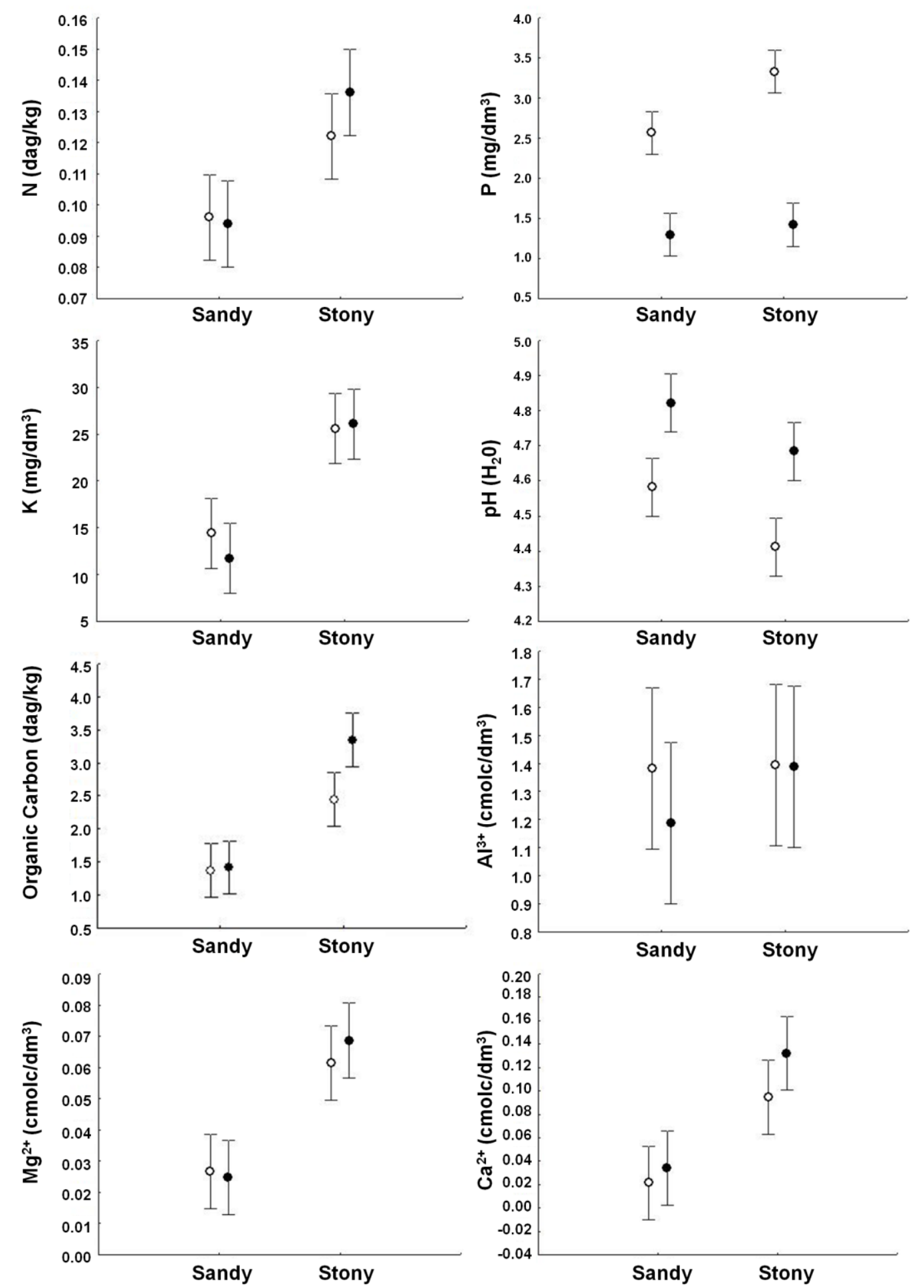

Figure 4 Mean and standard error values of chemical soil parameters, from soils collected in sandy and stony grasslands ( 3 samples $/ 5+5$ sites / 2 seasons, $n=60$ ). Open circles represent dry season and full circles rainy season. See Table 2 for two-way ANOVA results. 
St4
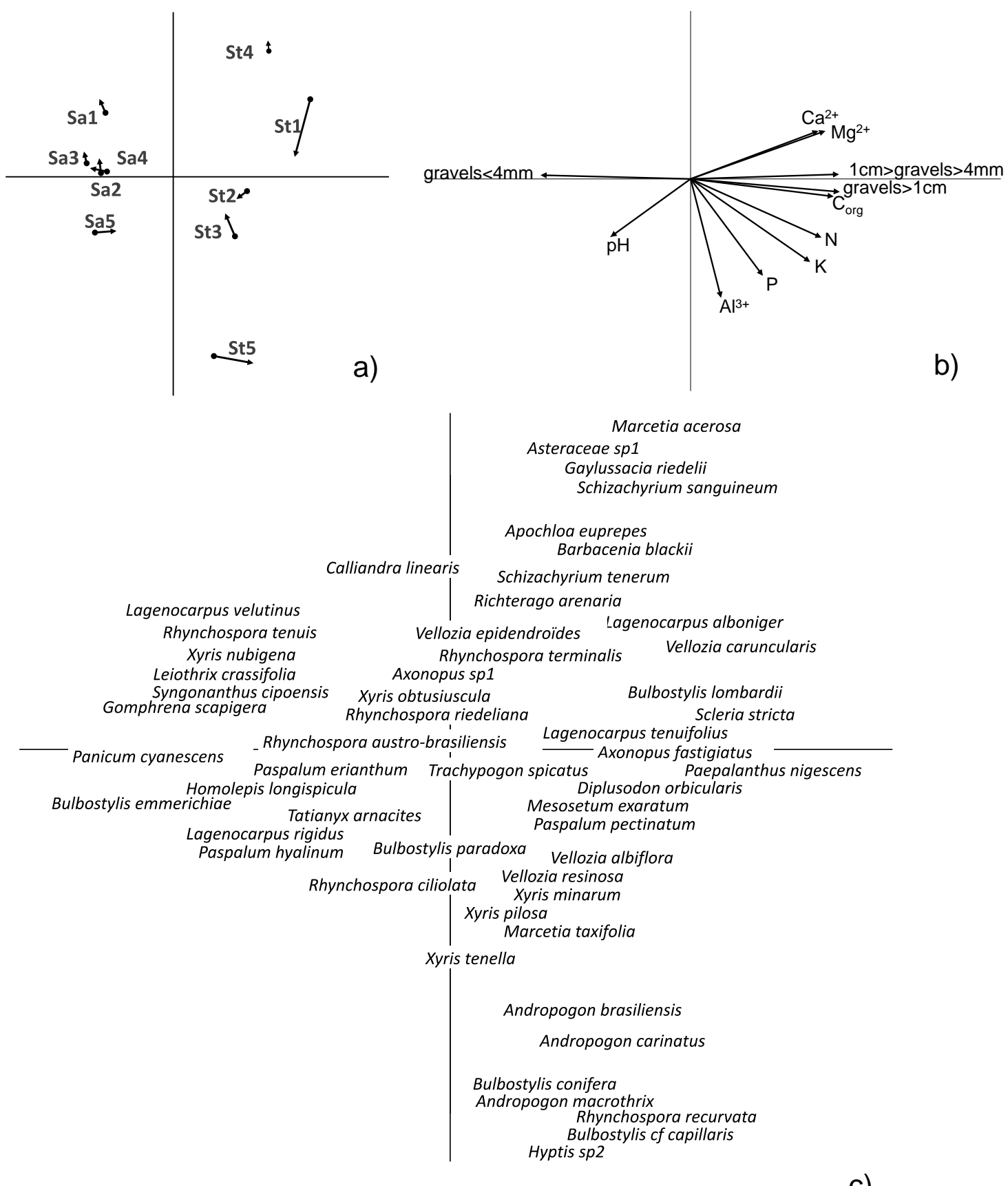

c)

Figure 5 Co-inertia results: a) Representation of the sites, arrow heads indicating floristic data and arrow tails indicating environmental data, b) Representation of the environmental data: soil composition and granulometry [10 points $\mathrm{x}$ 11 variables], c) Representation of the floristic data [10 points x 222 species]. Projection of the top two axes of the coinertia: axis 1: $79.4 \%$, axis 2: $10.5 \%$. RV test observations $=0.61, P<0.01$ (Monte-Carlo permutations). 


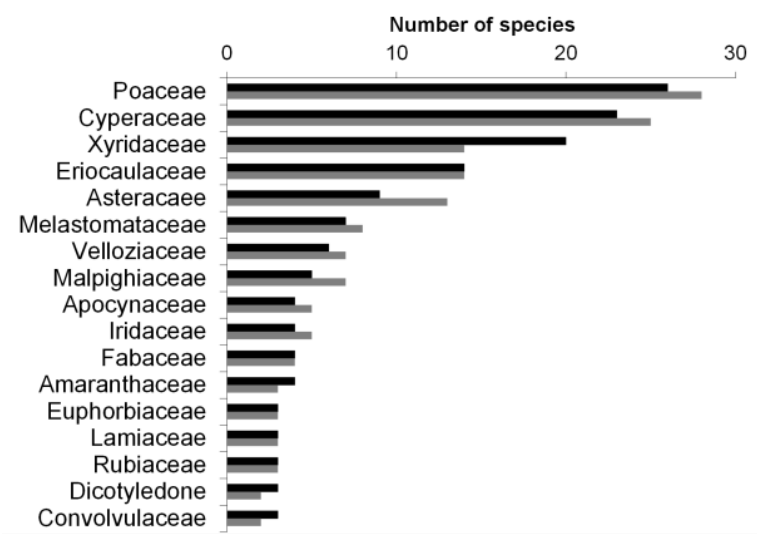

Figure 6 Number of species from the most-represented families in sandy grasslands (black columns) and stony grasslands (grey columns) (5 sites of each physiognomy, $15 \times 1 \mathrm{~m}^{2}$ quadrats in sandy grasslands and $20 \times 1 \mathrm{~m}^{2}$ in stony grasslands).

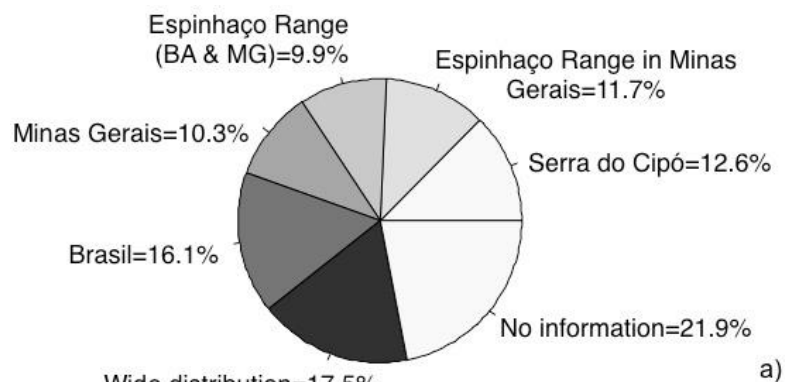

Wide distribution $=17.5 \%$

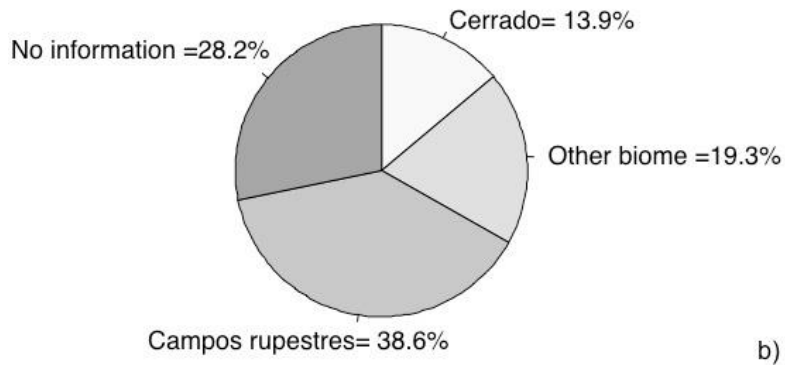

Figure 7 Pie charts representing the percentage of species according to a) their distribution range $(\mathrm{N}=174$ species $)$ and b) their habitat in Brazil ( $\mathrm{N}=160$ species).

Supplementary online material

Appendix 1. Plant list. Life forms (Raunkiaer (1904) modified by Mueller-Dombois and Ellenberg (1974)): He: Hemicryptophyte, CH: Chamaephyte, NA: Nanophanerophyte, HL: Hemicryptophytic Liana, GE: Geophyte, TH: Therophyte. Plant forms: F: Forbs, G: Graminoids, Ss: Sub-shrub, S: Shrub, L: Liana, Fe: Fern. Habitats in Brazil (Giulietti et al. 1987, Forzza et al. 2010): CR: Campos Rupestres, AG: altitude grassland, Ce: cerrado, Ca: Caatinga, AtR: Atlantic rainforest, AmR: Amazon rainforest, WG: wet grassland. Distribution range (Giulietti et al. 1987, Forzza et al. 2010, database SpeciesLink: http://splink.cria.org.br/): (a) Serra do Cipó, (b) Espinhço range in the state of Minas Gerais, (c) Espinhaço Range, (d) State of Minas Gerais, (e) Brasil, (f) Wide distribution. IUCN status (Fundação Biodiversitas para o Estado de Minas Gerais (Mendonça and Lins 2000)): VU: Vulnerable, CR: Critical, EN: Endangered. Life cycle: A: annuals and P: perennials. R: species observed resprouting after fire, empty cells mean no observation of the species in the burnt area. 